University of Chicago Law School

Chicago Unbound

Journal Articles

Faculty Scholarship

1997

\title{
Unifying Remedies: Property Rules, Liability Rules, and Startling Rules
}

Saul Levmore

Follow this and additional works at: https://chicagounbound.uchicago.edu/journal_articles

Part of the Law Commons

\section{Recommended Citation}

Saul Levmore, "Unifying Remedies: Property Rules, Liability Rules, and Startling Rules," 106 Yale Law Journal 2149 (1997).

This Article is brought to you for free and open access by the Faculty Scholarship at Chicago Unbound. It has been accepted for inclusion in Journal Articles by an authorized administrator of Chicago Unbound. For more information, please contact unbound@law.uchicago.edu. 


\title{
Unifying Remedies: Property Rules, Liability Rules, and Startling Rules
}

\author{
Saul Levmore ${ }^{\dagger}$
}

Imagine that $B$ complains about pollution spewing forth from a factory owned by her neighbor, $A$. A generation of law students has now learned that $B$ 's possible remedies traverse the boundaries normally drawn between legal subject areas, much as the previous generation of lawyers learned to lower the divide between law and equity. The educational watershed was surely Calabresi and Melamed's justly celebrated article of twenty-five years ago, suggesting a grand theory of remedies and concentrating on what it called property rules and tort liability rules.' By focusing on (and moving between) property rights, damage awards, and private bargains around these rights and awards, Calabresi and Melamed vaporized the inherited barriers between private law rights and remedies.

In retrospect, that article is at least as interesting for what it missed as for what it wrought. Readers of law reviews know that a good deal of attention had been paid to the question of when judges should assign property rights or liability awards, and Calabresi and Melamed can be said to have anticipated and initiated that inquiry - which I largely avoid in the present Essay. ${ }^{2}$ Some readers also know that Calabresi and Melamed might be described as having produced something less than a grand theory of remedies-if "grand" implies completeness-because subsequent innovators have shown remedies not anticipated twenty-five years ago. My aim here is, first, to learn about

i Brokaw Professor and Albert Clark Tate. Jr. Professor of Law. Universily of Virginia I am grateful for comments received from Laura Brodbeck, Jody Kraus, Daryl Levinson, Jeffrey Standen, and George Triantis, and for many conversalions with Bill Stuniz.

1. See Guido Calabresi \& A. Douglas Melamed, Propern, Rules. Labilin Rules, and Inalienability One View of the Cathedral, 85 HARV. L. REV. 1089 (1972).

2. Doubt has been raised about Calabresi and Melamed's analysis of when cours ought to prefer various remedies. See Ian Ayres \& Eric Tallcy. Solomonic Bargainung: Driding a Legal Entulement to Facilitate Coasean Trade, 104 YALE L.J. 1027 (1995) (disputung claim that propenty rules best encourage bargaining and arguing that liability rules and other "divided enutlements" have information-foreing qualities that lead to efficient outcomes); Louis Kaplow \& Steven Shavell. Do Labiliry Rules Facilitate Bargaining? A Reply to Ayres and Talley, 105 YALE L.J. 221 (1995) (challengung themes in Ayres and Talley's aricle); Louis Kaplow \& Steven Shavell, Property Rules Versus Labilin Rules: An Economic Analysis, 109 HARV. L. REV. 713 (1996) (arguing that liability rules are preferable to property rules for minimizing externalities even in cases where damages are difficult to determine) in the present Essay. 1 primarily explore the gamut of remedies rather than the question of when different remedies ought to be used, although I do on occasion cross the line into normauve territory. See infra Section III.A. 
remedies by exploring the nature of these renovations to the CalabresiMelamed framework, and second, to build on this framework in a way that yields substantial payoffs. I explore ways in which rights, remedies, and bargains can be combined to serve a variety of new tasks even while carrying on traditional efficiency, fairness, and redistributive functions. One particular finding is that rules that startle because they break a sensible convention-not asking those in the right to pay when they are wronged-can serve the interesting function of encouraging honest claims in the first place. The larger practical goal is to develop a more unified theory of remedies by showing how substantive and procedural considerations might be integrated.

Part I reviews the Calabresi-Melamed framework with a focus on the gaps it left unfilled. I explore in some detail a startling recent addition to the property and liability rules literature, authored by Professors Krier and Schwab. Calabresi and Melamed attracted attention, in large part, because they "found" a new and startling remedy in front of their readers' collective eyes; when $A$ 's behavior is a nuisance to $B$, a court might give $B$ the power to enjoin $A$, but it might require $B$ to pay $A$. Something about this split decision captivated most audiences even as it infuriated others, who found it too unusual to be of note. Krier and Schwab deepened the wedge by suggesting that there may be occasions when courts should decide that $A$ can choose to stop and collect damages (that $B$ would have suffered had $A$ not stopped) from $B$. Part II identifies the singularly startling quality found in this work and, by implication, in their predecessors' work a quarter century earlier. Part III argues that the real contribution of the more recent work to the development of a unified theory of remedies may be something quite unanticipated. Along the way, I develop some ideas about the arrows of time associated with various remedies and about the content of (surprisingly ambiguous) familiar remedies. Finally, in a way that might be said to echo Calabresi and Melamed's work, I suggest that the more complete framework we can construct today reveals yet more rules that may be of some use to courts.

\section{PROPERTY RightS AND Liability RULES ONCE MORE}

\section{A. The Four-Rule Framework}

Calabresi and Melamed were plainly not seeking to specify all of the remedial choices available to courts. Their exploration did include criminal law, and was therefore not limited to tort damages ("liability rules") and to (the issuance or denial of) injunctions regarding property rights ("property rules"); it

3. There was no attempt, however, to discuss choices among remedies normally found in criminal law. See Calabresi \& Melamed, supra note 1, at 1124-27 (discussing nature of criminal sanctions as propeny rules and suggesting reasons why liability rules would not be appropriate). 
did not, however, include remedies for breach of contract, burdensome unconstitutional statutes, or violations of international law. It is somewhat more difficult to specify the terrain that Calabresi and Melamed did intend to cover in their work. It seems a bit circular (and insufficiently appreciative of the genius of their framework) to take them almost at their word and say that their target included (only) all the disputes we normally think of as contained in property and tort law. ${ }^{4}$ Not only is property an elastic and ill-defined subject, but some of the value of the Calabresi-Melamed framework lies in its ability to illuminate fields outside of traditional property and tor law. Neverheless, inasmuch as the implicit collaborative goal of all who write on this matter is to develop a more complete framework, or a grander theory of remedies, it seems useful to take aim at the same target as one's predecessors. It may well be the case that an expanded set of remedies also covers a greater range of disputes, but I begin by returning to the very dispute Calabresi and Melamed brought on stage, a conflict among neighbors regarding an alleged nuisance.

By way of quick review, imagine that $B$ 's injuries could be avoided by $A$ shutting down its neighboring factory or, perhaps, installing a much taller smokestack to redirect its wastes. ${ }^{6}$ Calabresi and Melamed organized the remedial world we know by describing three possible "rules," and then observing that their description suggested the emergence of a fourth, previously unappreciated remedial possibility. Rule 1: $B$ might successfully enjoin $A$ from operating (or from operating without the more formidable smokestack). $A$ might, of course, negotiate with $B$ after losing in court in this manner but, with this Rule 1, the court will have established the starting point for such bargains. ${ }^{7}$ Rule 2: $A$ can be required to pay damages for injuries that $B$ has absorbed. ${ }^{8}$ Rule 3: $A$ can be permitted to continue as before-the inverse of Rule 1. After describing these three rules, Calabresi and Melamed sought to demonstrate the value of this categorization by suggesting that the inverse of Rule 2 might also

4. See id. at 1089 ("Only rarely are Property and Tons approached from a unitied perspective ")

5. See, e.g., Saul Levmore, Love It or Leav' It: Properry Rules. Lubilun Rules, and Exclusung of Remedies in Partnership and Marriage, LAW \& CONTEMP. PROBS. Spning 1995. at 221 (applying Calabresi-Melamed framework to remedies available in partnership law)

6. Thus, we might imagine that $A$ 's factory earns $\$ 10,000$ per year and injures $B$ to the tune of $\$ 5000$ a year, but that these damages could be reduced to $\$ 3000$ by invesung the equivalent of $\$ 1500$ per year in a taller smokestack. $B$ is presented as a single resident in this example and in the text, but It should be noted that although this simplification is troubling for arguments about the relauve desirability of property and liability rules, the present Essay has other aims.

7. Calabresi and Melamed's emphasis on such Coasean barganing might be understood as implicitly expanding the scope of their framework to include contract law and its remedies because the impact of these bargains around propeny and liability rules will depend on remedies for breath of contract

8. Continuing with the example from note 6, supra, A would pay $B \$ 2000$ per year (subject to a statute of limitations or other procedural constraint) for the past injuries suffered because the incremental damages caused by the absence of the efficient smokestack amount to $\$ 5000-\$ 3000=\$ 2000$ See SAUL LEVMORE. FOUNDATIONS OF TORT LAW 99 (1994) (posing question regarding valuatuon of incremental damages in a negligent accident example). If these numbers are hard to come by, courts might be expected to assess "full" damages of $\$ 5000$. If $A$ makes no changes, then $A$ can expect to pay the same next year, so that with these numbers we can expect $A$ to invest in the taller smokestack 
be used even though it was apparently unknown. The scheme was thus rounded out with Rule 4: $B$ stops $A$ but compensates $A$ for $A$ 's damages (such as relocation costs). ${ }^{9}$

TABLE 1. SUMMARY OF CALABRESI-MELAMED FRAMEWORK

\begin{tabular}{||l|l|l|l||}
\hline \hline RULE & \multicolumn{1}{|c|}{ DESCRIPTION } & \multicolumn{1}{|c|}{$\begin{array}{c}\text { FRAMEWORK } \\
\text { BULDER }\end{array}$} & \multicolumn{1}{|c|}{ COMMENTS } \\
\hline 1 & $B$ stops $A$ & $\begin{array}{l}\text { Calabresi-Melamed } \\
\text { (C-M) }\end{array}$ & $\begin{array}{l}\text { Classic injunction or "property } \\
\text { rule" }\end{array}$ \\
\hline 2 & $A$ pays $B$ & $\mathrm{C}-\mathrm{M}$ & Classic damages or "liability rule" \\
\hline 3 & $\begin{array}{l}A \text { can continue as } \\
\text { before }\end{array}$ & $\mathrm{C}-\mathrm{M}$ & $\begin{array}{l}\text { Reverse of Rule 1; } B \text { loses to } A \text { 's } \\
\text { property right }\end{array}$ \\
\hline 4 & $\begin{array}{l}B \text { stops } A \text {, but pays } \\
\text { A's damages }\end{array}$ & $\begin{array}{l}\text { C-M and Atwood; } \\
\text { see note } 9\end{array}$ & $\begin{array}{l}\text { Analogous to eminent domain, but } \\
\text { likely to involve low damages; see } \\
\text { note } 9\end{array}$ \\
\hline
\end{tabular}

Every reader of this Essay already knows that this four-rule framework revealed the ability of courts to choose among endowments, whether in the form of property rights (as in Rules 1 and 3) or liability rules (as in Rules 2 and 4), in order to balance considerations of fairness and efficiency. One strategy or the other might be favored because of the likelihood of judicial error in assessing costs and benefits, because of intuitions about parties' (and judges') abilities to overcome collective action and strategic behavior problems and other transaction

9. In this particular example, begun note 6 , supra, $B$ might pay $A$ the $\$ 1500$ (efficient) avoidance cost. I have argued elsewhere that in most nuisance cases these damages are unlikely to be high because the property right assignment normally follows changes that have benefitted the "loser" in financial terms. Thus, in Spur Industries v. Del E. Webb Development Co., 494 P.2d 700 (Ariz. 1972) (en banc), it is likely that the defendant's property value increased because of the encroaching residences. Defendants would of course be happier with a "double recovery" of property appreciation and the ability to sell the right to operate as before (Rule 3), but it is likely that even the prospect of single, extralegal recovery makes most potential defendants in these circumstances happy to see approaching residential development. For other examples of this sort of implicit compensation, see Richard A. Epstein, The Ubiquity of the Benefit Principle, 67 S. CAL. L. REv. 1369, 1386-87, 1399-402 (1994). Such implicit compensation can also be found in Mohr $v$. Williams, 104 N.W. 12 (Minn. 1905), in which the patient-plaintiff received a nominal damage award representing her actual damages for an unauthorized surgical procedure, less a "fee" to the defendant-physician for nonetheless beneficial services rendered. Note, however, that at the time Spur Industries itself was resolved, the Sun City residents had a suit pending against Spur for damages. Del Webb paid Spur to abate and relocate and Spur cross-complained against Del Webb, saying that it should be indemnified for damages that might be owed to the residents. The Arizona Supreme Court agreed that Del Webb might be liable, but the residents' case was settJed. See JESSE DUKEMINIER \& JAMES E. KRIER, PROPERTY 986 n.10 (3d ed. 1993).

As is well known, Calabresi and Melamed (along with an earlier commentator, see James R. Atwood, Note, An Economic Analysis of Land Use Conflicts, 21 STAN. L. REv. 293, 315 (1969)) correctly anticipated at least one nuisance decision using Rule 4, namely Spur Industries. Arguably, they also described another area of law with many more applications. See Levmore, supra note 5, at 238 (characterizing doctrine of wrongful dissolution in partnership law as example of $B$ stopping $A$ but paying $A$ 's damages from cessation). 
costs associated with bargaining, because of the likely redistributive or wealth consequences for bargaining itself, and because of sensibilities about the question of whether ex post payments legitimate (or grudgingly compensate) forced private transfers. ${ }^{10}$ My focus here, however, is on the framework itself, and on the range of possible rules or remedies that may be found.

It may be useful to comment on the role of Rule 4 ( $B$ stops $A$ but compensates $A$ ) in the Calabresi-Melamed framework, because of both its notoriety over the last twenty-five years and its importance in the discussion below. " One of the novel characteristics of the Calabresi-Melamed work was its trans-substantive character. Other scholars had enumerated, classified, compared, and even invented remedies, but the new approach was radical in its sweep across takings law, property rights, and tort damages with as broad (and confident) a brush as had been seen before. Conventional readers required a payoff from this reconceptualization. Rule 4 provided a kind of evidence that a new view of the cathedral would, as the exquisite title promised, reveal something not seen before. Another novelty was that the Calabresi-Melamed work showed that law and economics was something more than a taste for markets (and prices) and the worship of efficiency. Indeed, the article might be credited with making private law scholarship and judging respectable, economically sophisticated, and politically correct ventures. Judges could use property and liability rules to do what they thought efficient, fair, and even sensitive to concerns about wealth distribution. Rule 4 was instrumental in this regard inasmuch as it offered a remedy that shut down one party's operation in the interest of efficiency but then required compensation of the apparent winner. This sort of "separation" of remedial tools promised maneuvering space for judges.

\section{B. Other Property and Liability Rules}

\section{Filling in the Gaps}

One example of the genius of the early law and economics movement was its ability to conceptualize Rule 4 where thousands of lawyers had not seen it

10. See Calabresi \& Melamed, supra note 1, at 1106-10. Note that the judicial "error" assoctated with assessing damages may be virtually inevitable, or simply not designed to provide full compensation. so that it is possible to think of liability rules as less "complete" remedies than propenty rules. Compare Jeffrey Standen, The Fallacy of Full Compensation. 73 WASH. U. L.Q. 145 (1995) (analyzing and providing justification for incomplete remedies), with Jules L. Coleman \& Jody Kraus. Rethinking the Theory of Legal Rights, 95 YALE L.J. 1335 (1986) (discussing differences in concepts of compensation that flow from different definitions of rights).

11. Calabresi and Melamed themselves emphasized this aspect of their contnbution. and correctly so See Calabresi \& Melamed, supra note 1, al 1128 (The framework we have employed may be applied in many different areas of the law. We think its application facilitated perceiving and defining an addituonal resolution of the problem of pollution. As such we believe the panning to be Hell worth the oils.") 
before. ${ }^{12}$ It was perhaps easier for later commentators, empowered by the Calabresi-Melamed framework, to find other rules that were omitted twenty-five years ago. The best known of these additions is probably the idea that a court may sometimes wish to do something between Rule 1 ( $B$ can enjoin $A$ ) and Rule 2 ( $A$ pays $B$ 's damages). For instance, a court could enjoin $A$ from engaging in some level of operation, or from operating with a smokestack below some specified height, but then promise (or award) damages for injuries sustained by $B$ when $A$ operates within the specified parameters. We might refer to this remedy as Rule 1P, where $\mathrm{P}$ suggests either the author of this idea, Mitch Polinsky, or its poetic "partial property rule" character. ${ }^{13}$ Calabresi and Melamed might well have anticipated Rule 1P but thought of it as a mixture of their first two rules. Calabresi had, for example, spent many years thinking about negligence and strict liability, but he did not bother to split (the straightforward liability) Rule 2 in two, presumably so as not to weigh down the four-rule framework. ${ }^{14}$

Somewhat similarly, Rule 1 ( $B$ can enjoin $A$ ) comes in a variety of intriguing forms not explored twenty-five years ago. Calabresi and Melamed's references to property rules appear to conceive of those rules as including lesser liability remedies, ${ }^{15}$ so that their version of Rule 1 not only gives $B$ the right

12. It seems fair to give credit to the movement, rather than to the obvious powers of these particular authors, because another, earlier author also came to Rule 4, albeit from a different direction. See Atwood, supra note 9.

13. See A. Mitchell Polinsky, Resolving Nuisance Disputes: The Simple Economics of Injunctive and Damage Remedies, 32 STAN. L. REV. 1075, 1087 (1980) (arguing that entitlements need not be absolute). It has also been suggested that there could be a system of "comparative nuisance," similar to comparative negligence. See Jeff L. Lewin, Comparative Nuisance, 50 U. PITT. L. REv. 1009 (1989). In such a system, damage awards could be apportioned based on faimess, efficiency, and relative levels of causation. See id. at 1035-37. Lewin also suggests that injunctions could be awarded on a comparative basis, by requiring a successful plaintiff to compensate an enjoined defendant for an amount that corresponds to the plaintiff's comparative fault. Thus, in a comparative nuisance system, we might expect to sec more Rulc 4-type decisions. See id. at 1046-47.

14. There is Rule $2 \mathrm{~N}$, under which defendant pays damages when negligently causing harm, and Rule $2 S$, representing strict liability, requiring defendant to pay damages when causing injury. On the spectrum of remedies, Rule $2 S$ would occupy a space closer to Rule 1, in that it gives a "property right to damages" to plaintiffs. Most damages arising out of contract are of the Rule $2 S$ type, but Rule $2 S$ is sometimes used to penalize wrongdoing. This is so even in the context of contract remedies, because the remedy of rescission is limited to certain cases, including ones in which there is evidence of fraud, unilateral mistake known to the other party, and duress. Rescission may therefore be a version of Rule 2 or $2 \mathrm{~N}$ damages. See DOUGlas LAYCOCK, MODERN AMERICAN REMEDIES: CASES AND MATERIALS 580 (2d ed. 1994). In any event, Calabresi was no stranger to any of this. See Guido Calabresi \& Jon T. Hirschoff, Toward a Test for Strict Liability in Torts, 81 YALE L.J. 1055 (1972).

15. See Calabresi and Melamed, supra note 1, at 1116 ("Missing is a fourth rule representing an entitlement in Taney to pollute, but an entitlement which is protected only by a liability rule."). It should be noted, however, that the cases cited as Rule 1 examples by Calabresi and Melamed do not include damage awards. They cite Ensign v. Walls, 34 N.W.2d 549 (Mich. 1948), in which the court enjoined annoying dog breeding, as well as a case enjoining the production of chemical odors that later generated a successful suit for past damages, see Capurro v. Galaxy Chem. Co., 2 Envtl. L. Rep. (Envt. L. Inst.) 20386 (Md. Cir. Ct. 1972). See also Pendoley v. Ferreira, 187 N.E.2d 142, 146-47 (Mass. 1963) (enjoining operation of piggery and awarding past damages); Morgan v. High Penn Oil Co., 77 S.E.2d 682, 690 (N.C. 1953) (enjoining owner and operator of oil refinery and awarding damages to neighbors); Quinn v. American Spiral Spring \& Mfg. Co., 141 A. 855, 858 (Pa. 1928) (awarding past damages to resident living 
to stop $A$ but also anticipates that $B$ can collect from $A$ for past injuries resulting from the activity that $B$ succeeds in halting. ${ }^{16}$ Lawyers are familiar with injunctions that are forward-looking only, ${ }^{17}$ and many of these do not even glance back in the reparative sense, ${ }^{18}$ but again Calabresi and Melamed can be applauded for their elegance. Resting in between their Rules 1 and 2, we can picture the occasional use of other rules, useful when judges are disinclined to award past damages for reasons of faimess or even efficiency. ${ }^{19}$ Rule 1 ( $B$ can

adjacent to manufacturing plant and enjoining plant from keeping noisiest machines on side of building closest to plaintiff's house).

16. This assumption is somewhat problematic, because statutes of limitations are an obstacle to plaintiffs' awards for past damages, but not (at least explicitly) for injuncuve relief Also. combined injunctions and damage awards suggest a blurring of the distinction belween the roles of judges and junes Such a decision also spans the old divide between law and equity. although courts uf equity did dectue legal issues, despite apparent res judicata problems, even if the grounds for equitable relief no longer existed. See, e.g., Shaw v. Owen, 90 So. 2d 179. 181 (M1ss. 1956) (statung that courts of equity may and will decide issues of law to "award" by single comprehensive decree "all approprate temedies") Finally. it should be said that the mixing of the past with the future, through the novel device of using payments of money to remedy future harms, may serve to confuse thungs even as it opens new possibilities

Much as I am reading Calabresi-Melamed as emphasizing one version of Rule $I$ ( $B$ enjoins $A$ and collects past damages) but acknowledging through citations the possibility of a vanation (Rule IF $B$ stops $A$ and does not collect for the past), so too Rule 2 ( $A$ pays $B$ ) is set out as giving $A$ license to contunue as before by paying the price set out by the tort system but apparently recognizang the passibility of a court's terminating the license and converting Rule 2 to Rule l. by "sanctioning" $A$ if it conunues to be tortuous " We might think of this version as Rule $2 C$ : $A$ pays $B$, but if $A$ contunues $A$ might be told to stop The label refers to the convertibility of the damage rule (into a property rule) as well as to the idea that a labulity rule has some content that is not quite captured by the immediate remedy 1 provides See supra note 10 and accompanying text. After writing this Essay, 1 was fortunate to see Dale A. Nance. Gusdance Rules and Enforcement Rules: A Better View of the Cathedral (1996) (unpublished manuscript. on file with author), which emphasizes the distinction between the enforement and guidance qualutues of rules Rule $2 \mathrm{C}$ is a version of Rule 2, but might be listed best between Rule I and Rule 2 inasmuch as $t$ recognizes that the remedy of Rule 2 may signal the coming imposition of Rule I if $A$ 's oflending behavior conunues

17. We might call this Rule IF. An obvious example would be cases involving pnson overcrowding. in which courts are highly unlikely to grant successful plainuffs damages for the past Sec. $8 g$. Hutto $y$ Finney, 437 U.S. 678 (1978) (affiming order that conditıons of confinement in Arkinsas pnsons be improved). Examples also exist in nuisance. See. e.g. Ohıo Ruver Sand Co v Commonu ealth. $467 \mathrm{~S} W 2 \mathrm{~d}$ 347 (Ky. 1971) (enjoining industrial company that polluted atmosphere and waters and awarding plantuff one dollar in nominal damages); Dolata v. Berthelet Fucl \& Supply Co., 36 N W 2d 97 (W15 1949) (enjoining fuel company from blowing coal dust onto neıghbonng properues, but awarding no damages because "evidence is insufficient to sustain any definte amounts")

18. Some injunctions are thus forward-and backward-looking in that they repals past wrongs while taking steps to prevent continuing wrongs, such as antitust volations and flawed clection procedures See generally OWEN M. FISS, THE CIVIL RIGHTS INIUNCTION 7 (1978): Douglas Laycock. Tie Death of the Irreparable Injury Rule, 103 HARV. L. REV. 687. 77 I (1990).

19. One such rule (perhaps a subule form of Rule IF ( $B$ stops $A$ but gets nothing for the past)) could be used in cases where injunctions serve as a form of compromise. perhaps because damages are considered too speculative to assess. A good example is Champion Spark Plug Co y Sanders, 331 U S 125 (1947), in which the court required the seller of reconditioned Champron spark plugs to label such plugs clearly as "repaired" or "used," but did not award damages because the "lukelthood of damage to petultonet or profit to respondents due to any misrepresentation seem[ed] slight." Id at 131-32 Rule IE is also possible Plaintiff might be awarded an injunction plus defendani's past ennchment, rather than her own past damages. This might also be considered a form of compromise, since such a remedy would normally be less generous to plaintiff than Rule I ( $B$ stops $A$ and by implication collects for past damages) I have found no cases in which a court could easily have determined and awarded damages and instead chose for reasons of fairness or equity to award past enrichment. However, numerous examples can be found in which courts award past enrichment because monetary damages are impossible or difficult to determine A celebrated example is Edwards v. Lee's Administraror, 96 S.W.2d 1028 (Ky. 1936), in which iwo neighbors owned the land above a cave containing onyx formations. Edwards owned the land contanning the entrance to the 
enjoin $A$ ) can thus be seen as set out at one end of the remedy spectrum, with Rule 3 ( $A$ can continue as before without paying $B$ ) at the other end; Rule 2 ( $A$ pays $B$ 's damages) and Rule 4 ( $B$ stops $A$ but compensates $A$ ) are appropriate intermediate locations to have specified because they accommodate liability rules in simple fashion. The other rules that I have mentioned and alluded to were, perhaps, left as exercises to test the combinatorial skills of us mortal readers. ${ }^{20}$

TABLE 2. EXPANDED SET OF ANTI-NUISANCE RULES

\begin{tabular}{|c|c|c|c|}
\hline RULE & DESCRIPTION & SOURCE & COMMENTS \\
\hline 1 & $\begin{array}{l}B \text { stops } A \text { (and collects } \\
\text { for past injuries) }\end{array}$ & $\begin{array}{l}\text { C-M's apparent } \\
\text { Rule } 1 \\
\end{array}$ & $\begin{array}{l}\text { Injunction with likelihood of } \\
\text { damage collection }\end{array}$ \\
\hline $1 F$ & $\begin{array}{l}B \text { stops } A \text { but does not } \\
\text { collect for past injuries }\end{array}$ & & See notes $16-19$ \\
\hline $1 \mathrm{P}$ & $\begin{array}{l}B \text { stops } A \text { up to a point, } \\
\text { and } A \text { pays the damages } \\
\text { associated with its } \\
\text { permitted operation }\end{array}$ & $\begin{array}{l}\text { Polinsky; see note } \\
13\end{array}$ & Partial property rule \\
\hline $2 \mathrm{C}$ & $\begin{array}{l}A \text { pays } B \text {, but may be } \\
\text { stopped later on }\end{array}$ & $\begin{array}{l}\text { Hints in Coleman } \\
\text { \& Kraus, Nance }\end{array}$ & See notes 10,16 \\
\hline $2 S$ & $\begin{array}{l}A \text { pays } B \text { even if not } \\
\text { negligent }\end{array}$ & Partition of Rule 2 & Strict liability rule; see note 14 \\
\hline $2 \mathrm{~N}$ & Negligent $A$ pays $B$ & Partition of Rule 2 & $\begin{array}{l}\text { Negligence liability rule; see note } \\
14\end{array}$ \\
\hline
\end{tabular}

One last example of this expansive view of the four-rule framework concerns the absence of restitutionary remedies. Surely a judge could have the polluting factory, $A$, disgorge its enrichment from "unjustly" failing to invest in the efficient precautions that were available to it." Missing, therefore, is Rule

cave and admitted the public for a charge, taking them into the portion owned by Lee. The court awarded Lee an accounting of profits for the trespass, as well as an injunction prohibiting Edwards from further trespass on those lands. "The law, in seeking an adequate remedy for the wrong, has been forced to adopt profits received, rather than damages sustained, as a basis of recovery." Id. at 1032; see infra notes 21-27 and accompanying text.

For discussion of another, perhaps implicit, rule, see the discussion of Rule $2 \mathrm{C}$ in note 16 , supra: $A$ pays $B$ but may be more strongly encouraged to stop if underlying behavior continues.

20. One rule not mentioned is general average contribution in admiralty law, which (put simply) provides that in emergencies at sea, all the interests in a vessel and its cargo share the cost of sacrifice in proportion to the value. See GRANT GILMORE \& ChaRLES L. BLACK, LAW OF ADMIRALTY \$§ 5-1 to 5-2 (2d ed. 1975).

21. Continuing with the example from note 6 , supra, $A$ could pay the $\$ 1500$ per year that represents the avoided cost of the efficient taller smokestack. There are problems with this rule, but we might imagine cases where the legal system would add a small penalty in order to make sure that $A$ is not indifferent between precaution-taking and injury-inflicting, and where there is reason to think that no complex premium is needed to compensate for the probability that although $A$ 's behavior is antisocial, $B$ 's claim does not regularly materialize. See Saul Levmore, Probabilistic Recoveries, Restitution, and Recurring Wrongs, 19 J. LEGAL STUD. 691 (1990) (explaining normal preference for tort damages over restitution). 
TABLE 3. RESTITUTION-INSPIRED EXPANSION OF ANTI-NUISANCE REMEDIES

\begin{tabular}{|c|c|c|c|}
\hline RULE & DESCRIPTION & SOURCE & COMMENTS \\
\hline 1 & $B$ stops $A$ & $\mathrm{C}-\mathrm{M}$ & \\
\hline IE & $\begin{array}{l}B \text { stops } A \text { and } A \text { disgorges } \\
\text { earlier wrongful gains }\end{array}$ & $\begin{array}{l}\text { C-M combined } \\
\text { with restitution }\end{array}$ & $\begin{array}{l}\text { See notes } 19-23 \text { and } \\
\text { accompanying text }\end{array}$ \\
\hline 2 & $A$ pays $B^{\prime}$ s damages & $C-M$ & \\
\hline $2 \mathrm{E}$ & $\begin{array}{l}A \text { pays } B \text { its own unjust } \\
\text { enrichment }\end{array}$ & $\begin{array}{l}\text { Familiar } \\
\text { alternative (outside } \\
\text { of nuisance law) } \\
\text { to Rule } 2\end{array}$ & $\begin{array}{l}\text { See note } 21 \text { and accompanying } \\
\text { text }\end{array}$ \\
\hline
\end{tabular}

$2 \mathrm{E}$, where $A$ pays over its wrongful enrichment to $B$, as well as Rule $1 E^{22}$ where $A$ is enjoined as to the future and also expected to disgorge from the past. ${ }^{23}$ We have come to expect such rules to be attractive only where $B$ 's damages are significantly more difficult to measure than $A$ 's unjustly saved avoidance $\operatorname{costs}^{24}$ (or, perhaps, where these gains are a source of punitive damages), ${ }^{25}$ but a unified theory of remedies would presumably account for these tools. Again, it is a matter of taste whether one prefers the simplicity of a four-rule framework or the completeness that more rules might have offered. It would be wrong to describe Calabresi and Melamed as having "missed" these other remedies. The brooding presence of these remedies would have been fairly obvious, ${ }^{26}$ and their consequences fall within the range of the four-rule viewfinder. ${ }^{27}$

Note that there is also the possibility of combining restitution with stna liability rather than with negligence or wrongfulness. There are therefore at least two versions of what the text calls Rule $2 E$

There are also at least three different types of resutution in which the amount that the wrongdoer must restore to the plaintiff represents either its profits, the value of the used tiem in its next best use. or its full value. For a discussion of this tangential matter, see Peter K. Huber, Mtistaken Transfers and Profitable Infringement on Property Rights: An Economic Analysts, 49 LA L REV 71, 103-08 (1988)

22. See supra note 19 .

23. One advantage of such a rule is that $\mathrm{t}$ might overcome the histoncal disinclination to leave damage remedies to juries because the damage remedy was a malter of law rather than of equity See supra note 16.

24. See, e.g., Olwell v. Nye \& Nissen Co., 173 P 2d 652 (Wash 1946) (holdung that owner of eggwashing machine wrongfully used by defendant, but that otherwise would have been idle. recerves protit derived by defendant from use of machine).

25. See, e.g., Sturm, Ruger \& Co. v. Day. 594 P 2d 38. 50 (Alaska 1979) (Burke. J . dissentung in part) (describing use of cost of company's untaken precaution as amount of punuve damages). Grumshaw $v$ Ford Motor Co., 174 Cal. Rptr. 348, 388-89 (Ct. App. 1981) (cilung defendiant's net worth and previous year's income as evidence that punitive damage award was not excessive)

26. Put differently, Rules $1 E$ and $2 E$ might be of interest to a reader who secks a unified theory of remedies, but they are neither startling in the manner of Rule 4 nor critical in the construction of a remedies framework.

27. Similarly, although Calabresi and Melamed do incorporate some of takings law, see Calabresi \& Melamed, supra note 1, at 1106 , they ignore sovereign immunty. whuch might be thought of as creaung a Rule 3G: $A$ can continue as before if $A$ is the government. Note that $3 G$ can be more powerful than 3 In Miller v. Schoene, 276 U.S. 272 (1928), for instance, a stalc government was able to cradicale ornamental cedar trees (hosting parasites) that threatened nearby apple orchards without compensaung the cedar owners. If the apple growers had simply gone to coun alleging a prvale nutsance. they mighi have 


\section{Arrows of Time}

I have already suggested that a unified theory of remedies might pay more attention (than earlier work did) to purposeful slices of the spectrum of time. An injunction regarding property rights might (or might not) be purely prospective, so that there would be no damages for past inflictions. ${ }^{28}$ Similarly, while liability rules are generally backward-looking-albeit accompanied by the implicit threat of repeated, future damage claims if the actionable behavior continues $^{29}$-it is easy to imagine a forward-only liability rule. ${ }^{30}$ This sort of rule might be appealing either where the defendant seems culpable only once put on notice or where a kind of comparative negligence regime is best instituted through these slices of time (as opposed to slices of aggregate damages). ${ }^{31}$

Putting aside the capacity of a liability rule to be as forward-looking and as fine-like as any property rule, it is apparent that in most cases the convenient

been able to stop further planting of cedars, but I doubt that a court would have required the uncompensated destruction of existing cedars. This is not the place to explore the relationship among legislative, judicial, and private interventions, so I leave for another day the question of whether sovereign immunity is best thought of as an escape from a liability rule or as a property rule in favor of the government. Note, however, that governmental action, as in Miller, raises another version of the question about the relationship between judicial declarations and past damages. See supra notes 16-18. It is surprisingly difficult to divine whether the Miller court would have anticipated that after its decision the apple growers could collect for past damages suffered at the hands of the cedar-based parasite.

28. Rule 1 ( $B$ stops $A$ and by implication collects for past damages) can thus be contrasted with the forward-looking only Rule $1 \mathrm{~F}$, which is most closely analogous to conventional legislation. The contrast illuminates the intuition that Rule 1 includes damages for the past because it is often thought that a remedy for past injuries is necessary to ensure that meritorious claims are brought in the first place. To some extent, it seems that "purely prospective" remedies are the work of legislatures or administrative agencies, but of course judges can use declaratory judgments (which themselves will generate future damage recoveries in the event of violations) and injunctions with contempt sanctions to do much the same. See Douglas Laycock, The Triumpli of Equity, LAW \& CONTEMP. PROBS., Summer 1993, at 53, 79; see also United States v. Brotherhood of R.R. Trainmen, 95 F. Supp. 1019 (D.D.C. 1951) (ordering fine for civil contempt, where fine corresponded to plaintiff's loss from defendant's violation of injunction). See generally OWEN M. FISS, INJUNCTIONS 703-74 (1972) (analyzing details and implications of enforcing injunctions through contempt proceedings).

29. An example of a case explicitly granting damages for the future is Boomer v. Atlantic Cement Co., 257 N.E.2d 870 (N.Y. 1970), in which the court denied an injunction, but awarded permanent damages to the neighbors of a dust-blowing cement plant. We can also imagine a liability rule that is explicitly limited to the past, either because future behavior is enjoined or because circumstances have changed such that future injuries would not be regarded as wrongfully caused. Instances of such a backward-looking Rule $2 \mathrm{~B}$ include Allison v. Smith, 695 P.2d 791 (Colo. Ct. App. 1984), which held that weekend cabin owners could enjoin their neighbors from storing scrap metal and other "obnoxious debris" on their property, and awarded the owners $\$ 5000$ in damages; Edwards v. Lee's Administrator, 96 S.W.2d 1028 (Ky. 1936) (discussed supra note 19); and Morgan v. High Penn Oil Co., 77 S.E.2d 682 (N.C. 1953), which held that oil refinery emissions of noxious gases were actionable by neighboring trailer park and restaurant owner and remanded for a hearing on the facts.

30. I might label it $2 \mathrm{~F}$. If Rule $1 \mathrm{~F}$ is analogous to legislation prohibiting certain behavior, Rule $2 \mathrm{~F}$ can be compared to legislatively imposed fines for certain behavior. Again, lawyers tend to think that finesetting is a job for legislators. See supra note 27.

31. Instances of such a rule in the case law are difficult to find, but Champion Spark Plug Co, v. Sanders, 331 U.S. 125 (1947), and Boomer, 257 N.E.2d 870, can be seen as Rule 2F ( $A$ pays $B$ for future damages only) cases. In Champion, we can imagine that although the court held that an accounting of profits was not required and that an injunction "will satisfy the equities of the case," 331 U.S. at 132, future violations of the injunction might have been expected to lead to damages awards for Champion, see id. at 131-32. 
means of anticipatory judicial intervention is through injunctive, or property, rules. Given that Calabresi and Melamed classified along the property-liability axis, it is noteworthy but perhaps not terribly remarkable that there is also a time axis (primarily in the sense that legal intervention can be anticipatory or ex post) to be added, so that a liability rule can be forward- or backward-looking (or both) and a property rule, while forward-looking by nature, can include damages for the past. ${ }^{32}$

TABLE 4. EXPANSIONS BASED ON DIRECTION OF REMEDY AND OTHER EXPECTATIONS

\begin{tabular}{|c|c|c|c|}
\hline RULE & DESCRIPTION & SOURCE & COMMENTS \\
\hline 1 & $\begin{array}{l}B \text { stops } A \text { (and collects for } \\
\text { past injuries) }\end{array}$ & $\begin{array}{l}\text { C-M's apparent } \\
\text { Rule I } \\
\end{array}$ & $\begin{array}{l}\text { Injunction with likelihood of } \\
\text { damage collection }\end{array}$ \\
\hline $1 F$ & $\begin{array}{l}B \text { stops } A \text { but does not } \\
\text { collect for past injuries }\end{array}$ & & See notes $16-19$ \\
\hline $2 \mathrm{C}$ & $\begin{array}{l}A \text { pays } B, \text { but may be } \\
\text { stopped later on }\end{array}$ & $\begin{array}{l}\text { Hints in } \\
\text { Coleman \& } \\
\text { Kraus, Nance } \\
\end{array}$ & Sce notes 10,16 \\
\hline $\begin{array}{l}\text { General } \\
\text { Average } \\
\text { Contribution }\end{array}$ & $\begin{array}{l}\text { Nonnegligent } A \text { shares in } \\
B \text { 's loss if part of same } \\
\text { community }\end{array}$ & & See note 20 \\
\hline $2 \mathrm{~B}$ & $\begin{array}{l}A \text { pays only for past } \\
\text { injuries to } B\end{array}$ & & See note 29 \\
\hline $2 \mathrm{~F}$ & $\begin{array}{l}A \text { pays only for future } \\
\text { damages to } B\end{array}$ & $\begin{array}{l}\text { Legislative } \\
\text { practice }\end{array}$ & $\begin{array}{l}\text { See notes } 30-31 \text { and } \\
\text { accompanying text }\end{array}$ \\
\hline $2 \mathrm{X}$ & $\begin{array}{l}A \text { pays what } B \text { might have } \\
\text { extracted in a bargain if } B \\
\text { had property right to sell }\end{array}$ & Farber & $\begin{array}{l}\text { More generous damages than } \\
\text { Rule 2: see note } 48\end{array}$ \\
\hline
\end{tabular}

If the original Calabresi-Melamed framework had been built around forwardlooking and backward-looking rules, a later observer could just as easily slice in another direction by introducing the property-liability axis. ${ }^{33}$ The emphasis on

32. See supra notes 16-17,29 and accompanying text (suggesung that Calabresi-Niclamed's verston of Rule 1 was probably meant to include past damages, but calling Rule IF ( $B$ stops $A$ but docs not collect for past damages) a version that does not). Note that an injunction caln verge on a call for future damages because the penalty for civil contempt can amount to nothing more than modest damages See supra note 31 .

33. For example, a framework built on the time axis might have offered. (1) remedies that look forward only; and (2) remedies that look both forward and backward. The introduction of (3). remedies that look backward only, might then have been as starling as Calabresi and Melamed's Rule $\&$ ( $B$ stops $A$ but compensates $A$ ), because most awards for past damages at least implicidy suggest thal further antusocial activity will result in future successful suits by one's neighbors Fonvard-looking only remedies could come in at least four varieties, corresponding to Calabresı and Melamed's properiy and liabilaty rules, as could dual-direction, forward- and backward-looking rules. Exclusively backward-looking rules, however, would make sense only in the form of liability rules, because injuncuons regarding past behavior ate mure the stuff of morality plays than of law. 
property rules and liability rules spawned a literature on transaction costs and default rules, ${ }^{34}$ while an earlier focus on the timing of intervention and the direction of the intervention (whether forward or backward or both) would have encouraged the law and economics literature to explore both the division of labor between judges and legislatures, ${ }^{35}$ and isomorphically perhaps, the ripeness doctrine $^{36}$ and the question of private standing where there is public harm.

\section{Krier and Schwab's Startling Extension}

In 1994, Jim Krier and Stewart Schwab imaginatively suggested a rule under which $A$ can stop (itself) and then collect $B$ 's damages-that is, those damages that will now not be borne by $B$ because $A$ has stopped. ${ }^{37}$ Krier and Schwab

34. See, e.g., sources cited supra note 2.

35. Legislatures are often said to be in the business of forward-looking rulemaking, while judges decide actual cases or controversies that have already matured. Note that the judge-legislature choicc has become a topic in the public choice literature. See, e.g., Einer Elhauge, Does Interest Group Theory Justify More Intrusive Judicial Review?, 101 YALE L.J. 31 (1991) (comparing interest group problems found in litigation and judicial intervention with those found in legislative decisionmaking).

36. Put differently, it is not easy to explain why $B$ has some chance of gaining an injunction against the operation of $A$ 's factory next door, while $B$ has little chance of such anticipatory relief from another neighbor who reliably drives too fast down the block each day. It is possible that the role of fines in the administrative state is more central than it at first appears, in that the system may count on $B$ 's ability to convince a police officer to observe $A$ 's behavior and issue a summons at very low cost both to the legal system and to $B$. It is also possible that the explanation lies in some complicated combination of considerations regarding error costs, measurement costs (which may be much the same thing as the irreparable injury rule), and the comparative advantages of juries, judges, and legislatures. Similarly, many claims dismissed for lack of ripeness may be understood as addressing the roles of juries and legislatures (rather than the suitability of later damage suits against the same court). See, e.g., Nicholson v. Connecticut Half-Way House, Inc., 218 A.2d 383 (Conn. 1966) (overturning injunction against start of operations of halfway house for parolees).

37. Note that this is different from Rule $1 E$ described above; Rule $1 E$ entitles $B$ to stop $A$ and reccive $A$ 's untaken past precaution cost as a kind of restitution paid by the wrongdoer to the aggrieved party. Krier and Schwab give $A$ an option that, when exercised, works to stop $A$ in return for B's payment of $B$ 's forgone damages. See James E. Krier \& Stewant J. Schwab, Property Rules and Liability Rules: The Cathedral in Another Light, 70 N.Y.U. L. REV. 440, 471 (1995). The Krier-Schwab notion is thus closer to Rule 4 ( $B$ stops $A$ but compensates $A$ ) than to Rule $1 E$, in that $B$ pays, but its real interest derives from some combination of offering $A$ an option and linking liability to $B$ 's "gain" rather than $A$ 's past gain (as in Rule 1E) or $A$ 's cost of compliance (Rule 4).

The idea of giving $A$ an option, or even an option leading to a reverse "sale," did not originate with Krier and Schwab. It has strong roots in the idea of self-assessed taxes and damages, and it has been grafted onto the nuisance literature in Madeline Morris, The Structure of Entitlements, 78 CoRNELL L. RBV. $822,854-56$ (1993), which described put options as examples of reverse liability rules, in which the "inkind" holder has both an exclusive veto power and the right to a forced compensated transfer. See also Ayres \& Talley, supra note 2. For an expanded discussion of such put options and the way these options might be auctioned, see Ian Ayres \& J.M. Balkin, Legal Entitlements as Auctions: Property Rules, Liability Rules, and Beyond, 106 YALE L.J. 703, 729-33 (1996). Similarly, the idea of expanding Calabresi-Melamed by taking advantage of the notion that there is a range over which $A$ and $B$ can bargain is older than KrierSchwab and Morris. For one example of an emphasis on the range and indefinite number of potential initial bargaining points, see WILLIAM A. FISCHEL, THE ECONOMICS OF ZONINO LAWS: A PROPERTY RIGHTS APPROACH TO AMERICAN LAND USE CONTROLS 113-14 (1985). Krier-Schwab, Morris, and Ayres-Talley were working contemporaneously with these twists and tools.

Krier and Schwab may startle readers who come to their work last (although my own startle reflex was surely enhanced by the fact that I read Krier-Schwab in a draft form before I encountered the picces by Morris and Ayres-Talley) by referring neither to a prenegotiated option price (familiar in the world of options, but less interesting in nuisance and other conflicts) nor to an up-front offer (as suggested in Morris, 
frame this as a choice put in $A$ 's hands in order to exploit the fact that $A$ is sometimes best situated to decide whether the socially preferred result is to cease or to continue operations. ${ }^{38}$ This choice thus sometimes devolves into Rule 3 ( $A$ may continue as before with no payments required), because $A$ may choose to continue (perhaps because her gains from continuing exceed $B$ 's damage claim despite the court's contrary estimate), and sometimes into what I will call Rule 5. It is useful to emphasize that when $A$ stops and collects, it is the complainant's enrichment that is extracted.$^{39}$ Plainly, the availability of Rule 5 must come as something of a surprise to $A$, and perhaps to $B$ as well. If $A$ knew that a judge would respond to any complaint by $B$ with this Rule 5 , then $A$ would have a perverse incentive to create nuisances in order to collect from $B$. Indeed, as we will see, an element of the strategy implicit in Rule 5 is to encourage parties to be wary of judges' discretion and to gamble, if it can be called that, on the likelihood that a cour will impose one remedy or another.

The more general strategy is to "subsidize" behavior that is sought from $A$ rather than to "tax" $A$ for the costs it externally imposes. When $A$ is offered the choice between Rule 3 (continuing its operation as before) and Rule 5 ( $A$ stops and collects $B$ 's gain from the cessation), $A$ may essentially be paid to stop being a nuisance. The Calabresi-Melamed framework emphasized bargaining from initial positions imposed by (or expected of) courts, and Krier and Schwab can be seen as following this lead by suggesting yet another bargain that might have taken place between $A$ and $B$ in a world where $A$ was armed with the properny right to do as it pleased. I will suggest below that the most useful-but perhaps unambitious-way to think of these rules is to note that while Rule 4 ( $B$ stops $A$ but compensates $A$ ) asks for the minimum amount $A$ would require in order to take the precaution in question, Rule 5 can be understood as asking for the maximum amount $B$ would pay.

The four-rule framework advances and manipulates the familiar idea that most sticks have corresponding carrots, so that both regulatory strategies and private bargains will usually come in pairs. In a somewhat obscure footnote,

supra, at 855 (describing police offer of twenty-five to fifty dollars to induce those possessing guns to tum them in)) but rather to a judicial decision that sometimes turns $B$ 's complant into an option avallable to A. Put differently, we normally think of bangains, including pnvately offered options. as making both parties better off, but Krier-Schwab elevate the possibility, as discussed infra in Section II B, of doing no such thing. In any event, the present Essay suggests that we sometumes remove the option clement from the "reverse liability" rule. See infra text accompanying note 69

38. $A$ is sometimes the best chooser because $1 \mathrm{thas}$ the best information about us own avoldanice costs. and frequently is free of the collective action problems that might plague $B$. the neighbor

39. As indicated, the Krier-Schwab idea is to be able to offer $A$ a choice belween Rules 3 ( $A$ "wins" in the sense of being allowed to continue as before with no payments required) and 5 ( $A$ chooses to stop in order to collect $B$ 's "forgone" damages). It is unlikely that we would ever want to make Rule 5 mandatory, although the option has been mistakenly suggested elsewhere See Levmore, supra note 5. at 234 n.42. A will shy away from Rule 5 when $A$ 's gauns from conunuing exceed even the high level of payment captured in $B$ 's damage allegations. In these situations we will be especialty huppy that we did not shut $A$ down. If, for some reason (such as strategic pleading). B's actual damages exceed $B$ 's alleged damages, $B$ may be able to pay $A$ more than the Rule $S$ amount in order to get $A$ to stop 
Krier and Schwab shuffle and deal another such pair by suggesting a rule under which $A$ must choose between cessation and turning over its own enrichment. ${ }^{40}$ Rule 5 looked to the objector's ( $B$ 's) enrichment, but now we look for the defendant's ( $A$ 's) gains from continuing as before. A court might decide that $A$ can choose either to undertake a specific precaution such as building a taller smokestack (or stopping altogether), and neither pay nor collect, or to go on as before by paying $B$ the amount determined in court to be $A$ 's (untaken) precaution cost. ${ }^{41}$ I will call this Rule $5 \mathrm{CE}$ because the defendant can choose to continue and disgorge its own enrichment, although I should emphasize that what is suggested is really giving $A$ the power to choose between Rule 5CE and Rule 1 ( $A$ is stopped). ${ }^{42}$ Krier and Schwab hint that the choice between offering Rule 5 ( $A$ stops itself but collects $B$ 's alleged gain from this cessation) and Rule 5CE ( $A$ chooses to continue, rather than to stop and perhaps pay for the past, and $A$ pays over its gain from continuing as before) might depend on a judge's assessment as to which party is the best decisionmaker. ${ }^{43}$ But both rules just sketched seem to suppose that $A$ is a good decisionmaker; one asks $A$ to absorb the cost of continuing while the other asks $A$ if it is willing to absorb the opportunity cost of forgone income associated with stopping. The strategy has a self-assessment component to it, but that is not a topic I wish to dwell on here. $^{44}$

40. See Krier \& Schwab, supra note 37, at 473 n.92. Note that Kricr and Schwab secm at first to be setting out a mandatory rule that $A$ must stop, but they go on to say that $A$ holds a "trump" and can simply avoid rather than pay the costs of avoidance.

41. Note that the restitution in Rule 5CE draws on $A$ 's gain from continuing, while that found in Rulo 5 points to $B$ 's gain from $A$ not continuing. Rules 5 and SCE are thus unrelated, or at least more distant relatives than other numerical pairs set out here; in Rule 5, $A$ both stops and collects $B$ 's enrichment, while in Rule $5 \mathrm{CE}, A$ both continues and pays based on its own enrichment. Returning to our hypothetical factory and neighbor, see supra notes 6,8 , in Rule 5 the enrichment to be collected is what $B$ gains from $A$ 's cessation, which is $B$ 's (incremental) loss in the event that $A$ continues, or $\$ 2000$. But in Rule SCE the enrichment to be paid derives from the unspent avoidance, or cessation, costs and is $\$ 1500$.

42. Assume now that $A$ claims that the better smokestack, see supra text accompanying note 41 , costs $\$ 3000$, and $B$ 's incremental injury from the absence of this precaution is still $\$ 2000$. If the judge suspects that $A$ 's true avoidance costs are $\$ 1500$, then following Rule $5 C E$ the judge might offer $A$ a choice between stopping (or improving the smokestack, and owing past damages under Rule 1) and continuing without the new smokestack-but then paying $\$ 3000$, the alleged gain from not taking the precaution that the judge suspects is efficient.

43. I do not mean that a judge would offer $A$ a choice between Rules $S$ and SCE. Unless the measurement problem is out of control, Rule 5 will always be vastly more attractive to $A$. The "choice" is the judge's; $A$ can be offered a choice between Rule 5 and continuing as before, which is to say betwcen Ruies 5 and 3, or $A$ can be offered a choice between $5 C E$ and stopping, which is to say between Rules $5 C E$ and 1 .

44. See Saul Levmore, Self-Assessed Valuation Systems for Tort and Other Law, 68 VA. L. REV. 771 (1982) (discussing value and advantages of self-assessment as tool for overcoming valuation problems). 
TABLE 5. SUMmaRY OF REMEDIES RELATED TO AND INSPIRED BY KRIER AND SCHWAB

\begin{tabular}{|c|c|c|c|}
\hline RULE & DESCRIPTION & SOURCE & COMMENTS \\
\hline $2 \mathrm{E}$ & $\begin{array}{l}\text { A pays its unjust } \\
\text { enrichment }\end{array}$ & $\begin{array}{l}\text { Well-known } \\
\text { alternative to C-M's } \\
\text { Rule } 2\end{array}$ & $\begin{array}{l}\text { IE could do the same with } \\
\text { injunction plus restitutuonary } \\
\text { payment arising out of past injunes }\end{array}$ \\
\hline 3 & $\begin{array}{l}A \text { can continue as } \\
\text { before }\end{array}$ & $\mathrm{C}-\mathrm{M}$ & Reverse of Rule $1, B$ fails in court \\
\hline 4 & $\begin{array}{l}B \text { stops } A \text {, but pays } A \\
\text { (at least } A \text { 's } \\
\text { relocation costs) } \\
\end{array}$ & C-M and Atwood & $\begin{array}{l}\text { Analogous to private eminent } \\
\text { domain but likely to involve low } \\
\text { damages }\end{array}$ \\
\hline 5 & $\begin{array}{l}A \text { stops and collects } \\
B \text { 's ("unsuffered") } \\
\text { gain from this } \\
\text { cessation; } A \text { can } \\
\text { instead elect to } \\
\text { continue as before } \\
\text { (Rule 3) }\end{array}$ & $\begin{array}{l}\text { Krier-Schwab"s (K-S) } \\
\text { "double reverse } \\
\text { twist" modified }\end{array}$ & $\begin{array}{l}\text { K-S have court determine } B \text { 's } \\
\text { enrichment. } A \text { choosing whether to } \\
\text { stop and accept this amount; the } \\
\text { present Essay converts this to a } \\
\text { claims-control tool sueh that } A \\
\text { collects what } B \text { claimed she would } \\
\text { have suffered }\end{array}$ \\
\hline $5 \mathrm{CE}$ & $\begin{array}{l}\text { A chooses to continue } \\
\text { as before but then } \\
\text { must pay its } \\
\text { enrichment in being } \\
\text { allowed to do so }\end{array}$ & K-S & $\begin{array}{l}\text { See notes } 40-13 \text { and accompanying } \\
\text { text; see also text accompanying } \\
\text { note } 69 \text { on modifying this rule to } \\
\text { encourage aceurate claims by } A\end{array}$ \\
\hline
\end{tabular}

\section{UNDERSTANDING THE STARTLE ReFleX}

\section{A. Dissecting Krier-Schwab}

Krier and Schwab cite no cases applying or anticipating their idea, and I have suggested elsewhere that there may be reasons (other than a lack of judicial and lawyerly imagination) for the emptiness of this set. ${ }^{\text {"s }}$ Nevertheless, it may be useful in systematizing remedies to identify the novelty of Krier-Schwab and to see whether this contribution can be further generalized.

One possibility is that the novelty of Rule 5 ( $A$ stops itself but collects $B$ 's alleged gain from this cessation) is that it can fall outside the range contemplated by Calabresi-Melamed. $B$ will normally be disappointed with a Rule 3 decision (allowing $A$ to continue) and increasingly pleased ${ }^{\text {to }}$ with Rule 4 ( $B$ stops $A$ but compensates $A$ ), Rule 2 ( $A$ pays $B$ 's damages), and Rule 1 ( $A$ is stopped and normally owes damages). Technically speaking, it is of course the case that all of these rules understate $B$ 's victory, if it is that, because after any one of these

45. See Levmore, supra note 5, at 234; infra notes $52-58$ and accompanying tcxt

46. This is more or less the case anyway. There are umaginable situations in which $B$ 's preterences would not be represented by this ordering. For example, $B$ may place a higher premum on $A$ 's stopping and would therefore prefer Rule 4 to Rule 2. 
rules is imposed, $A$ may bargain with $B$ and leave $B$ (as well as $A$ ) better off than the initial judicial decision. ${ }^{47}$ Similarly, Rule 3 ( $A$ can continue as before) may leave $A$ even better off than it first appears. Still, a fair reading of Calabresi-Melamed may be that Rules 1 ( $B$ stops $A$ ) and 3 ( $A$ can continue) define the two ends of the decision spectrum available to judges in civil cases of a certain (not quite specified) kind. Rules 2 ( $A$ pays $B$ ) and 4 ( $B$ stops $A$ but compensates $A$ ) seem to offer compromises, or intermediate positions, through the introduction of the liability tool. In any event, the Krier-Schwab innovation (Rule 5's offer to $A$ that it can stop and collect $B$ 's gain from this cessation) gives $A$ a bigger victory than the four-rule framework appears to have anticipated. Under their approach, $A$ can still choose Rule 3, which is to say that $A$ can continue as before or entertain offers from $B$ (who may want to pay $A$ to stop), but $A$ is obviously better off with the ability to choose between Rule 3 and Rule 5, which allows $A$ to stop and to collect handsomely (in the amount of $B$ 's gain from $A$ 's cessation).

If, as just intimated, Krier-Schwab have simply leveraged four rules into something of a larger shape, then their creation might play a role in developing a comprehensive list of remedies-but it would hardly present the cathedral in a new light. Thus, the introduction of punitive damages would also have made $A$ or $B$ better or worse off than did the "extreme" property rules, 1 ( $A$ is stopped) and 3 ( $A$ may continue); however, the absence of punitive damages from the four-rule framework surely demonstrates nothing more than that Calabresi and Melamed sought elegance rather than completeness. Much as we would hardly have been startled by a suggestion that the four-rule framework be extended to include punitive damages, the novelty of the Krier-Schwab work cannot derive from its generating a remedy more extreme than those found in the first four rules.

Somewhat similarly, the striking character of Rule 5 probably does not come from its clever use of $B$ 's unsuffered damages. These damages reflect one of two possible sources of payment based on restitution, while Rule $5 C E$ ( $A$ chooses to continue and pay over its gain from continuing as before) draws on the other source. Once again, it would be disappointing if the true root of the novelty resided in the introduction of something that Calabresi-Melamed and a generation of readers compressed rather than failed to comprehend. I have already suggested in Part I that the four-rule framework ignores many possible

47. To be sure, that improvement may be anticipated by the judge. Note in this regard that CalabresiMelamed and the discussion in the present Essay ignore remedies that might be described as anciently empathetic or internalizing, such as noxal surrender (goring ox is itself handed over to successful plaintiff) or talionic liability (eye for an eye). These remedies must generally have been "avoided" by bargains reached in their shadow, but their character might well have expanded the range of likely bargaining outcomes (beyond the range enclosed in modem times by the Calabresi-Melamed rules) and left the victim better off than before. But this is not the place to advance the cause of comparative study; it is mercly useful to see that a theory of remedies that sought to specify all known and conceivable remedies would be as long as the history of legal experimentation and imagination. 
rules that can appear fair and efficient but that feature restitution rather than damages as their centerpiece. To the extent that the Krier-Schwab innovation camouflages the introduction of a tool from the restitution family, where a taste for elegance held it offstage before, the startling reaction comes from a sleight of hand. ${ }^{48}$ In any event, if restitution is the key, then Krier and Schwab themselves missed many other, more useful rules than the ones they sketch. ${ }^{\text {.9 }}$

Finally, the character of the Krier-Schwab innovation is not captured either by what they emphasize as the "choosing function"\$0 they seek to encourage or by the observation that the winner in terms of property rights can be the loser in terms of payments. It is true of course that $A$ might be best situated to decide whether or not it is socially efficient to continue as before, so that giving $A$ a choice between stopping and continuing can be sensible, but the original Rule 2 ( $A$ pays $B$ 's damages) was explicitly designed (by the father of least cost avoidance analysis) to perform just such a choosing, or least cost avoiding, function. If $B$ 's complaint about $A$ 's nuisance-making leads to a liability rule in $B$ 's favor, then whatever the intended arrow of time, ${ }^{\text {s1 }}$ Calabresi-Melamed plainly thought that an advantage of such a liability rule was that $A$ would sometimes decide to cease or modify its operation in order 10 avoid paying future damages. Rule 2 ( $A$ pays $B$ ) thus assigned to $A$ the choosing function even (or especially) in the absence of easy bargaining between the paries. As for the separation of objectives or tools, Rule 4 ( $B$ stops $A$ but compensates $A$ ) already demonstrated the idea of making one party stop but another pay. ${ }^{52}$ The same move would not startle us twice.

In the end, I think that what is startling about the Krier-Schwab idea is quite different from what is promising and systemically interesting about it. Its initial

48. Put differently, if Calabresi and Melamed had offered a six-rule framework with restututun included, then Krier and Schwab's innovation would stull have been outside the range contemplated by Calabresi-Melamed, but it would have seemed more an interestung recombination or piece of leveraging

Note the possibility of a compromise rulc, calling for damages to be pad by $A$ but in the more generous amount that $B$ might have been willing to accept if $B$ had been assigned a property nght as in Rule 1. Such a rule contains an element of restitution because it extracts some of $A$ 's gan This rule is advanced in Daniel A. Farber, Reassessing Boomer: Jusfice, Efficiency; and Nutsance Lam. in PkuptkTr LAW AND LEGAL EdUCATION: ESSAYS IN HONOR OF JOHN E. CRIBBET 7 (Peler Hay \& Mlicharl H Hoeflich eds., 1988). Farber is attracted to Rule 1 or (where more feasible) to this compromise Rule $2 X$ (A pays what $B$ might have extracted in a bargain had Rule 1 been in effect), beciuse of a sense that in cases of egregious nuisance, $A$ comes close to "stealing" $B$ 's pror entulements See td at 13-19

49. See supra notes $17,21-27$ and accompanying text.

50. That is, they emphasize that the pany with the best information that can make decisions most cheaply should be the party to choose whether the behavior should be stopped or contunued This means that in "double reverse twist" cases, as they describe what I have called Rule $S$ (A stops itself and collects $B$ 's gain from the cessation), the party that does the choosing (the polluter) is not the same party that pays (the neighbors). See Krier \& Schwab, supra note 37, at 471. For a general discusston of whether these remedies should be chosen by plaintiffs or courts, see DAN B DOBBS, HANDBOOK ON THE LAW OF REMEDIES 13-23 (1973).

51. See supra Subsection I.B.2.

52. It might be said that Rule 5 ( $A$ stops and collects $B^{\prime}$ 's gann) innovates with its use of the idea of separating functions and using a subsidy because Rule 4 separaled funcuons but used a tax I would not have thought that this distinction could be so impressive. Moreover, it is arguable that the payment in Rule 4 , while described as a liability rule, is just as casily called a subsidy 
impact has little to do with the choosing functions if only because it is Rule 5 ( $A$ stops itself and collects $B$ 's gain from such cessation), rather than the choice between Rule 5 and Rule 3 ( $A$ continues), that is captivating. Instead, my sense is that we are too accustomed to entertaining the restitution tool only (and even then infrequently) where the loser's enrichment is "unjust." Rule 5's unbundling of the property right and liability results, such that one party stops doing business as usual while the other disgorges, is surprising because the disgorger is apparently neither wrongful nor unjust. The rule is about just enrichment rather than unjust enrichment. Viewed from a different perspective, albeit perhaps by process of elimination, what startles is that the degree of separation (between the property right and liability rule winners) is sufficient to make it plausible that the objecting party, $B$, will be left worse off than before. It happens that this feature, discussed presently in the next Section, is precisely what threatens to make the Krier-Schwab innovation self-destructive or at least rare (in a way that I think its authors did not fully anticipate), if only because $B$ will no longer want to bring suits as the likelihood that her own complaints will make her worse off increases.

\section{B. Penalizing the Victim}

If a judge follows Krier-Schwab and allows the defendant, $A$, to continue on as before or instead choose to stop but then collect $B$ 's (projected but not yet suffered) damages, $B$ may well be sorry that she brought her complaint. It is not just that legal fees will have been wasted either when $B$ loses, in the manner of Rule 3 , and the injunction against $A$ is denied, or when $A$ opts for Rule 5 ( $A$ stops and collects $B$ 's gain from this cessation) so that $B$ gets what she asked for in harm-preventing terms, but only by paying her full reservation price. ${ }^{53}$ The problem from $B$ 's perspective is that $B$ might not have been willing to pay this amount in order to stop $A$. Armed with the legal right to be free of pollution, $B$ might have demanded $\$ 100,000$, for example, before allowing $A$ to send effluents her way, so that $B$ 's damages from $A$ 's operation can fairly be said to amount to $\$ 100,000$; but this does not mean that $B$ could or would pay this amount to stop $A$, if the law requires $B$ to pay in order to change the status quo of $A$ 's operation. The wealth effect of the property right might itself cause $B$ to spend something less than $\$ 100,000$ on clean air. This well-known offer-asking differential, or endowment effect, may often be small enough to ignore ${ }^{54}$ but inasmuch as every penny of $B$ 's potential gain from

53. That is, $B$ would have been willing to pay up to $\$ 2000$ to be free of $A$ 's pollution in the example considered supra in notes $6,8,41$. However, $A$ would have been willing to sell the right to pollute for as litule as $\$ 1500$.

54. For a discussion of the endowment effect, see Mark Kelman, Consumption Theory, Production Theory, and Ideology in the Coase Theorem, 52 S. CAL. L. REv. 669, 673 (1979); and Duncan Kennedy, Cost-Benefit Analysis of Entitlement Problems: A Critique, 33 STAN. L. REV. 387, 401-22 (1981). 
$A$ 's cessation is here sought, the problem is likely to be present and significant in most instances. ${ }^{55}$ There is something of an analogy here to the annoying insistence of a teacher that a student's request for the regrading of an exam will be entertained only on the condition that the student bear the risk that, when the exam is reviewed, it may be determined that the grade should be decreased rather than increased. ${ }^{56}$

A subtle (or even subconscious) comprehension of this problem may well be at the heart of what is startling about the Krier-Schwab innovation. $B$ complains that $A$ 's smokestack configuration causes $B \$ 100,000$ in harm, and the shocking suggestion is that $A$ can go on as before or choose to shut down (or alter the smokestack) and collect $\$ 100,000$ from $B$. Even readers who are unfamiliar with the offer-asking literature may intuit that $B$ is not indifferent, but is now worse off than before. None of the other rules threatens $B$ in this manner. ${ }^{57}$ Indeed, the companion rule, $5 \mathrm{CE}$, introduced by Krier-Schwab as theoretically isomorphic to Rule 5, does not seem at all startling. It will be recalled that this companion rule also draws on the restitution idea as it offers $A$ the choice between stopping (Rule 1) and continuing at the cost of paying (to $B$ ) $A$ 's own gains from continuing rather than stopping (Rule $5 \mathrm{CE}$ ). The fact that this proposal does not seem nearly as interesting as its partner, Rule 5 ( $A$ stops and collects $B$ 's gain from cessation), suggests again that it is neither the choosing function nor the restitutionary quality that generates surprise, but rather the fact that only in Rule 5 is it the case that $B$ can emerge worse off than before. ${ }^{58}$

It goes almost without saying that Rule 5 ( $A$ stops itself and collects $B$ 's gain from this cessation) must be deployed cautiously. As noted earlier, there is the moral hazard that $A$ will engage in an activity in order to induce a

55. A sloppy correction would be to redraft Rule 5 to provide either that $B$ can be forced by $A$ to disgorge some percentage of $B$ 's gain from $A$ 's cessalton, or that the coun should take the offer-asking differential into account in assessing the payment required of $B$

56. The analogy to the offer-asking problem can be improved by noung that to make the regraung risk symmetrical and perhaps less obnoxious or self-serving. the teacher might lose something (or the student might be doubly rewarded) if the review proves the student correct. Tony Waters was grastous enough to point out the analogy to the British practice with respect to criminal appeals $A$ court revicwing a criminal sentence can raise as well as lower the penalty, while crimunil defendants in $U S$ courts have less to lose from complaining. This contrast makes certain assumptuons about the governmeni's behavior in cross-appealing and it also raises interesting and more general questons about the link between allowable responses to appeals (broadly understood) and rules of standing (as in who can appeal and how often). but I leave these interesting positive and normative matters for another day

57. Again, I leave out legal fees, because it might be suggested that the Bntush Rule threatens $B$ in this manner and yet such a rule would. without stanting. make a list of possible remedies mote comprehensive.

58. The surprise may also come from the separation of the choosing functuon from the paying function because Rule 5 reflects that separation while Rule SCE (A chooses and A pays) does not and Rule 4 entals not choosing and paying (because $A$ is offered no choice) but the separation of stopping from paying But I suggested earlier that it was Rule 5 and not the choice (between Rules 5 and 3 ) that started $A$ judictal decision requiring $A$ to stop and collect $B$ 's (unsuffered) damages (subject to $B$ 's ability to bargann around this decision) would stante. I think, without this separation. 
complaint and then profit from stopping and collecting. ${ }^{59}$ The possibility that a judge will use Rule 3 ( $A$ may continue as before) presents much less of an encouragement for $A$ 's strategic, inefficient location; not only is the potential payment from $B$ greater in Rule 5, but also with Rule 3, $B$ can simply decline to offer to pay $A$, so that $A$ will lose out if it has located simply to extract payment from $B$. In contrast, Rule 5 forces $B$ to pay at $A$ 's insistence and, therefore, poses more of a moral hazard problem. Put differently, if Rule 5 is in each judge's portfolio, then there is the risk that $B$ will be truly harmed by an antisocial, inefficient $A$, but will nevertheless decline to object for fear that she will trigger a Rule 5 decision and be yet worse off. $B$ must think that there is a substantial chance of victory in the form of the judicial imposition of Rule 1 ( $A$ is stopped), Rule 2 ( $A$ pays $B$ ), or any of a number of other rules in order to complain about $A$ 's wrong.

\section{UNIFYING SUBSTANTIVE AND LITIGATION-CONTROLLING REMEDIES}

\section{A. Deterring Excessive Claims}

In retrospect, an interesting way to describe the expansion of the four-rule framework over the last twenty-five years is that from an initial shape designed around the three most common patterns of judicial decisions, the framework has been stretched to cover the entire bargaining range. Given the default (and alienable) character of most of these "rules," it is almost surprising that the stretching has gone so slowly unless the thinking has been that default rules should rarely amount to corner solutions. ${ }^{60}$ Rule 5 ( $A$ stops and collects $B$ 's gain from the cessation) extracts from $B$ all that she could possibly want to pay to stop $A$, while Rule $5 C E$ ( $A$ continues but pays its gain from doing so) calls for the most $A$ would be willing to pay in order to be allowed to continue rather than stop. ${ }^{61}$ If a judge's goal is to generate efficient and fair default rules, taking into account the likelihood and outcomes of private bargains following the case-by-case issuance of judicial decisions or default positions, ${ }^{62}$ it may be hard to see why Rule 5 or 5 CE would ever be selected. ${ }^{63}$ Indeed, this probably explains both why Krier and Schwab use

59. Note that this is true even if Rule 5 is redrafted to award but a fraction of $B$ 's claimed damages. See supra text accompanying note 54 (describing potentially limited impact of offer-asking problem).

60 . We generally expect the result of bargaining between parties to produce some type of compromise solution; that Rule 5 would be the result of a bargain therefore strikes us as counterintuitive. Again, it seems unlikely that $B$ would accept Rule 5 in a bargaining context, as it may leave her worse off than under the status quo.

61. Perhaps we should think of each rule as demanding payment of one dollar less than what has been described in the text (and by Krier-Schwab) in order to make it seem plausible that the chooser might actually select either of the proffered options.

62. I include bargains reached in the shadow of judicial decisions, but based on the partics' understanding of what is likely to happen to them if their case is taken to court.

63. Hard, but not impossible. There may be times when Rule 5 makes sense, for instance, because $A$ 's 
each of these options only as an element of a choice offered to the better decisionmaker, and why Calabresi and Melamed might not wish that they had set out these options twenty-five years ago (instead of, or in addition to, the straightforward victory and loss for $A$ represented by Rules 1 and 3 , respectively) as a way of defining the end points of the decisionmaking (and bargaining) spectrum.

There is, however, potential value to Rule 5-and to other rules as well-that is easy to miss. It will seem at first that if $A$ chooses to stop and extract $B$ 's "gain," rather than to continue as before, then it is often pointless or dangerous for the legal system to incur the transaction costs of the assessment of damages and transfer from $B$. A has revealed that its avoidance costs are less than $B$ 's damages, and the same choosing function could have been assigned through Rule 2 ( $A$ pays $B$ 's damages); the threat of damages would have caused $A$ to stop and it would normally seem unjust-and risky in moral hazard terms ${ }^{64}$-for the antisocial $A$ to collect from the victim, $B .^{65}$ But if we modify the Krier-Schwab idea so that, instead of asking the court to assess $B$ 's would-be damages, we inser into Rule $5 B$ 's alleged damages, then we can appreciate the value of offering $A$ a choice between Rule 3 ( $A$ can continue) and Rule 5 ( $A$ stops and collects $B$ 's gain from the cessation). This choice combines some least cost avoidance, or "choosing," with a novel check on $B$ 's allegations. Rule 5 can serve to control $B$ 's temptation to overstate her damages in an attempt to convince the court that Rule 1 ( $A$ is stopped) or Rule 2 ( $A$ pays $B$ ), for example, is appropriate. ${ }^{66} B$ will recognize that an overstatement can lead to disaster because if a judge uses Rule 5 , then $B$ will need to pay the amount stated as if $B$ gains that amount from the decision to stop $A$. The occasional use of Rule 5 -or giving $A$ the choice between Rules 3 ( $A$ can continue) and 5 ( $A$ stops itself and collects $B$ 's gain from the cessation)-will encourage $B$ to be careful in her allegations about the facts that are most in her control. The beauty of this particular incentive for better self-assessment or litigation behavior is that there is no additional threat to

avoidance costs are surely less than $B$ 's damages, and there is an intutuon that $A$ should be patd something more than $A$ 's own avoidance costs.

64. At the very least, there is the danger that $A$ will set up the anusoctal acuvily near $B$ in order to induce a complaint and possibly profit from a decision following Rule 5 . Or course, the day after collecting $B$ 's damages, $A$ will simply go elsewhere or perhaps not operate anywhere al all In that case. perthaps the moral hazard only arises where the court has incorrectly and overgenerously computed $A$ 's avoidance costs On the other hand, inaccurate assessments may be inevitable.

65. However, Rule 5 may be attractive where $A$ is the more sympathenc party or B's claum is dufficult to verify.

66. Again, Rule 5 will be most useful where the judge has litle or no information and where the judge is not known to overuse this approach. There are, to be sure. other means of encouraging accurate selfassessments, beginning with occasional independent inquiries by courts (and penalues for exaggerations), but this sort of further expansion of the range of remedies is beyond the scope of this Essay The information-forcing component of this Essay could be seen as expanding on the discussion in Ayres \& Talley, supra note 2, at 1062-65. 
efficiency when it is misapplied ${ }^{67}$ Judges can use this rule when they sense that $B$ has overstated her potential damages from $A$ 's operations. ${ }^{68}$ Even if this is a misassessment, however, $A$ will still perform the choosing function and continue its operation as before only when $B$ 's damages are less than $A$ 's avoidance costs. The rule is thus information-forcing in the important sense that it controls $B$ 's incentive to overassess potential damages. Put differently and less optimistically, there is something to offset the moral hazard (and offer-asking) problem associated with Rule 5: The gains from more accurate allegations by $B$ may sometimes exceed the costs associated with creating conflicts where none would have materialized in the absence of the availability of Rule 5.

Inasmuch as it too is based on what might be thought of as maximum hypothetical restitution, Rule 5CE ( $A$ continues but pays its gain from doing so) shares this ability to deter excessive claims but with respect to $A$ rather than $B$-and only if $A$ is not given a choice between remedies. The possibility that a judge will require $A$ to continue as before but disgorge its alleged avoidance costs (now saved because Rule 1 ( $A$ is stopped) was not selected) will encourage $A$ not to overstate its avoidance costs. $A$ may press for Rule 3 ( $A$ can continue), for example, by trying to convince the court that its avoidance costs are truly high while $B$ 's damages are low, but the threat of Rule 5CE can control the temptation to overstate one's avoidance costs. Moreover, if the court errs in its estimate that $A$ has exaggerated, the social harm is limited because $A$ is, after all, permitted under SCE to continue operating as before. Finally, the worst outcomes in efficiency terms are avoided, as usual, so long as the parties manage to bargain. If, for example, $A$ has greatly overstated its avoidance costs and the court responds with $5 \mathrm{CE}$, then $A$ can offer to stop in return for $B$ 's agreeing to accept something less than the alleged avoidance costs that $A$ has been told to pay. The point is that $A$ cannot simply avoid this obligation by now choosing to stop. ${ }^{69}$

\section{B. Combining Substantive and Procedural Remedies}

The original four-rule framework did not ignore the realities of litigation and factfinding. Its authors suggested that a judge's choice among remedies

67. This assumes that $B$ can cheaply ascertain her own actual damages. Note that the incentive to engage in some combination of self-assessment and appraisal of what courts and adversaries will think and do is analogous to that provided by a variety of well-known schemes in systems with and without a background rule of fee-shifting. For example, Rule 68 of the Federal Rules of Civil Procedure, FBD. R. Crv. P. 68, aims to encourage offers of settlement and the acceptance of reasonable offers by attaching a cost to continued litigation following what appears ex post to have been a reasonable offer of settlement.

68. Of course, they can also use it when considerations of faimess recommend it; I have already suggested that such situations will be extremely rare.

69. This is contrary to Krier and Schwab's version of this rule, in which the polluter is the chooser and the avoidance costs are those that are determined by the court. Note that for simplicity's sake I am assuming that $A$ knows well its own avoidance costs. 
might be based on the judge's degree of confidence about the relative magnitude of damages and benefits, as well as the likelihood of collective action problems or other impediments to bargaining. ${ }^{70}$ The capacity of courts to assess these things, both systematically and in case-by-case terms, was plainly understood to enter the calculus of selecting among remedies. Nor was this a new way of thinking, for the field of remedies had been long accustomed to integrating substantive remedies with factinding considerations. For example, the "irreparable injury" mantra, invoked by a court confident enough to issue ex ante injunctive relief, and therefore inclined to say that ex post damages would not make the plaintiffs whole, reflects the very same thinking about property rules versus liability rules. ${ }^{71}$ Somewhat similarly, the additional procedural burdens placed on plaintiffs who seek preliminary injunctions reflect serious thinking about substantive decisions (and errors) and procedural rules. ${ }^{72}$ Nevertheless, there is a tendency in thinking about rights and remedies to exile or hold constant some "procedural" considerations. Thus, discussions about remedies take the plaintiff's burden of persuasion as given, with no attention paid to the possibility that the choice between damages and injunctive relief, for example, might be linked to this burden (or to switching it). ${ }^{73}$ More provocatively, the choice between negligence and strict liability, or, for that matter, between damages and injunctions, might be linked to the acceptability of contingency fees. ${ }^{74}$ Similarly, the choice between partial and full property rules might be tied to the terms of fee-shifting rules. ${ }^{75}$ We are not yet accustomed to thinking about these kinds of substantive-procedural connections. It is common to recognize such things as the ability of courts to shift legal costs and to levy penalties for inappropriate discovery behavior when attempting to construct a complete list of remedies, but it is uncommon to integrate these items in a way that illuminates the choices among more "substantive" remedies. I have tried to suggest that with modest effor such unification is possible and worthwhile. I suspect that the next twenty-five years

70. See Calabresi \& Melamed, supra note 1, at 1122

71. Doug Laycock has suggested that the irreparable injury rule actually does very litile work in explaining cases. See, e.g., Laycock, supra note 28, at 54-55 ("When I say" that the trreparable injury rule is dead, I do not mean that judges no longer talk about it in opinions Rather. I mean that the rule is always satisfied, so that it never constrains a court's decision in any case where the choice of remedy matters ")

72. Thus, plaintiffs may be required to post a bond before seeking a preliminary injunction The bond assures defendants of compensation in the event that they are injured by a preluminary injunction that was wrongfully granted. See FED. R. CIV. P. 65, 65.1.

73. Thus virtually every rule in the expanded Calabresi-Melamed framework could be further subdivided with alterations in the burden of proof.

74. It is apparent that the plaintiff's attomey, working on a contungency fee basis, wall prefer to win liability awards rather than property "rights." This preference may in turn affect the ideal use of these rules by judges.

75. The idea is that if parial victories avoid penalues for refusing setulements or cost-shuftung in systems built around a fee-shifting, or Briush, rule, then there is likely to be some feedback as to the appropriateness of the substantive rule itself. 
will see great strides on this front, with the links between substantive and procedural rules more clearly understood than they are today.

\section{CONCLUSION}

The exploration of links between remedies and procedures and the development of new rules (of the kind introduced here and in the earlier works to which I have referred) reinvigorate the Calabresi-Melamed framework. These research paths will guarantee, I predict, the continuing place of the Calabresi and Melamed article as one of the most cited and important law review articles of all time, and as one of a very few pieces that influenced a generation of scholars at the same time that it educated students new to the law. One particular advance suggested here is that, when we explore that which is most startling about the property and liability rules literature and recognize the importance (and availability) of information-forcing rules, we can expand the scope of the original four-rule framework with more reconceptualization than added complexity. Calabresi and Melamed's success in linking rights and remedies and in creating an elegant framework capable of accommodating many remedies can be extended to introduce tools that control strategic litigation. And the limits of the bargaining range reveal specific - and even startling-tools that can control strategic litigation without much risk of inefficient results. 
APPENDIX: SUMMARY OF REMEDIES

\begin{tabular}{|c|c|}
\hline RULE & DESCRIPTION \\
\hline 1 & $B$ stops $A$ and collects for past injuries \\
\hline $1 \mathrm{E}$ & $B$ stops $A$ and $A$ disgorges earlier wrongful gains \\
\hline $1 \mathrm{~F}$ & $B$ stops $A$ but does not collect for past injuries \\
\hline $1 \mathrm{P}$ & $\begin{array}{l}B \text { stops } A \text { up to a point, and } A \text { pays damages associated with its lawful } \\
\text { operation }\end{array}$ \\
\hline $2 \mathrm{C}$ & $A$ pays $B$, but may be stopped later on \\
\hline $\begin{array}{l}\text { General } \\
\text { Average } \\
\text { Contribution }\end{array}$ & Nonnegligent $A$ shares in $B$ 's loss if part of same community \\
\hline $2 S$ & $A$ pays $B$ even if not negligent \\
\hline 2 or $2 \mathrm{~N}$ & Negligent $A$ pays $B$ \\
\hline $2 \mathrm{E}$ & $A$ pays $B$ its own unjust enrichment \\
\hline 2B & $A$ pays only for past injuries to $B$ \\
\hline $2 \mathrm{~F}$ & $A$ pays only for future damages to $B$ \\
\hline $2 \mathrm{X}$ & $A$ pays what $B$ might have extracted if $B$ had property right to sell \\
\hline 3 & A can continue as before \\
\hline 4 & $B$ stops $A$ but pays $A$ (at least $A$ 's relocation costs) \\
\hline 5 & $A$ stops and collects $B$ 's gain from this cessation: $A$ could opt for Rule 3 \\
\hline $5 \mathrm{CE}$ & A chooses to continue but pays its own enrichment from doing so \\
\hline
\end{tabular}


HeinOnline -- 106 Yale L.J. 2174 1996-1997 